\section{Commentary: Like the children of Lake Wobegon: All aortic cannulation strategies are above average}

\author{
Louis H. Stein, $\mathrm{MD}, \mathrm{PhD},{ }^{\mathrm{a}}$ and \\ John A. Elefteriades, MD ${ }^{\mathrm{b}}$
}

Each patient with pathology of the ascending aorta presents a unique set of challenges for the cardiovascular surgeon. No single arterial cannulation strategy suits every patient. The extent of aorta to be corrected, other vascular pathology, and cerebral protection strategy influence choice. As the standard of care for aortic surgery recommends increasing extent of repair, each cannulation strategy must be carefully evaluated. No one strategy fits all.

The femoral artery can be cannulated before sternotomy. Cardiopulmonary bypass before sternotomy can provide welcome security in the setting of a contained rupture. The authors of this commentary prefer the safety of a femoral cutdown, which does mean an additional incision. Using femoral cannulation, cerebral protection can be performed with straight deep hypothermic circulatory arrest. Selective antegrade cerebral perfusion (SACP), if desired, requires direct innominate and left carotid cannulation. Extension of a DeBakey I dissection into the femoral arteries may limit the use of femoral arteries. Heavy femoral atherosclerosis (although rare in ascending dissectors) can prohibit the use of femoral cannulation.

Cannulation along the innominate-subclavian-axillary axis typically allows for SACP through the right carotid

\footnotetext{
From the a Division of Cardiothoracic Surgery, Department of Surgery, Albany Medical College, Albany, NY; and ${ }^{\mathrm{b}}$ The Aortic Institute at Yale-New Haven Hospital, New Haven, Conn.

The authors reported no conflicts of interest.

The Journal policy requires editors and reviewers to disclose conflicts of interest and to decline handling or reviewing manuscripts for which they may have a conflict of interest. The editors and reviewers of this article have no conflicts of interest.

Received for publication March 12, 2020; revisions received March 12, 2020; accepted for publication March 13, 2020; available ahead of print April 4, 2020.

Address for reprints: Louis H. Stein, MD, PhD, Division of Cardiothoracic Surgery, Albany Medical Center, Surgeons Pavilion, 3rd Floor, 50 New Scotland Ave, Albany, NY 12208 (E-mail: steinl1@amc.edu).

JTCVS Techniques 2020;2:8-9

2666-2507

Copyright (C) 2020 The Authors. Published by Elsevier Inc. on behalf of The American Association for Thoracic Surgery. This is an open access article under the CC BY-NCND license (http://creativecommons.org/licenses/by-nc-nd/4.0/).

https://doi.org/10.1016/j.xjtc.2020.03.023
}

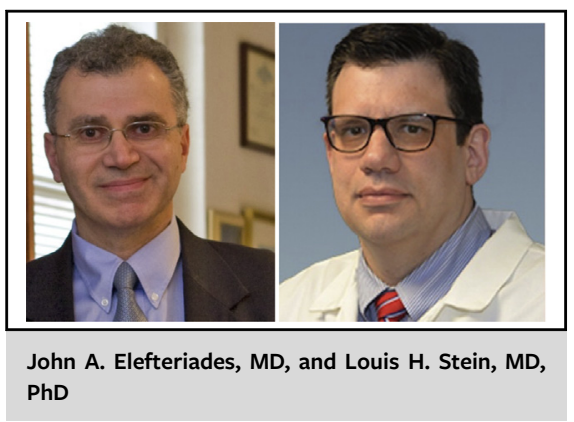

CENTRAL MESSAGE

Like the parents of Lake Wobegon, many surgeons are sure they have the one best cannulation strategy. In a world of increasingly complex disease, its best to have a few "aboveaverage" techniques.

artery by clamping the at the base of the innominate. The axillary artery is frequently cited as a preferred location for cannulation. It requires a variable amount of extra time to perform. The resultant incision and anastomosis are out are out of the surgeon's view during the procedure and a potential source of blood loss. The axillary artery can be very fragile and prone to injury. Preventza and colleagues ${ }^{1}$ reported on innominate artery cannulation. This strategy provides a configuration for SACP. The innominate artery can be limited by being foreshortened. As the first major branch of the aorta, its proximity can result in involvement with primary aortic pathology.

In this issue of the Journal, Norton and colleagues ${ }^{2}$ report an intrathoracic subclavian artery cannulation technique. This synthesizes the benefits of the innominate and axillary cannulation techniques. It is amenable to SACP and provides distance from the aorta but does not necessitate a separate incision. The outcomes are similar to the innominate cannulation strategy presented by Preventza and colleagues $^{1}(\mathrm{n}=68)$ : SACP time: 20 minutes and stroke rate of $4.4 \%$. The mortality rate appears lower in the study of Preventza and colleagues ( $1.5 \%$ vs $5.2 \%)$, although direct comparisons of 2 studies with small sample sizes is difficult. ${ }^{1,2}$

Previous publications have demonstrated excellent results with other techniques. Recently, direct Seldinger cannulation via a simple purse string has facilitated both femoral and even axillary cannulation. Axillary cannulation is expedited 
substantially by this technique. ${ }^{3,4}$ We would also ask Norton and colleagues if they would consider expediting their subclavian cannulation technique by direct cannulation.

Treatment of proximal and transverse aortic disease necessitates consideration of a complex variety of anatomy. As in Wobegon, the proponents of each cannulation technique feel their method is best. However, a "one size" of cannulation technique may not fit all patients. It is to the surgeon's benefit to have multiple tricks up their sleeve to address the patient's unique anatomy and pathology. We thank Norton and colleagues for their contribution.

\section{References}

1. Preventza O, Bakaeen FG, Stephens EH, Trocciola SM, de la Cruz KI, Coselli JS Innominate artery cannulation: an alternative to femoral or axillary cannulation for arterial inflow in proximal aortic surgery. J Thorac Cardiovasc Surg. 2013; 145: S191-6.

2. Norton EL, Makkinejad A, Le T, Wu X, Yang B. Intrathoracic right subclavian artery cannulation in aortic arch surgery. J Thorac Cardiovasc Surg Tech. 2020; 2:1-5.

3. Carino D, Mori M, Pang PYK, Singh M, Elkinany S, Tranquilli M, et al. Direct axillary cannulation with open Seldinger-guided technique: is it safe? Eur $J$ Cardiothorac Surg. 2018;53:1279-81.

4. Tsiouris A, Elkinany S, Ziganshin BA, Elefteriades JA. Open Seldinger-guided femoral artery cannulation technique for thoracic aortic surgery. Ann Thorac Surg. 2016;101:2231-5. 